\title{
岐阜薬科大学附属薬局における電話相談内容の解析調査
}

\author{
小長谷奈美 ${ }^{1}$, 長内理大 ${ }^{1,2}$, 小俣江利果 ${ }^{1}$, 島内あか $\eta^{1}$, 伊野陽子 ${ }^{1,2}$ \\ 玉木啓文 ${ }^{1,2}$, 山下修司 ${ }^{2,3}$ ，野口義紘 ${ }^{2,4}$ ，井口和弘 ${ }^{1,2}$, 寺町ひとみ*2,4 \\ 岐阜薬科大学薬局薬学研究室, ${ }^{1}$, 岐阜薬科大学附属薬局 ${ }^{2}$ \\ 岐阜薬科大学実践社会薬学研究室 ${ }^{3}$, 岐阜薬科大学病院薬学研究室 ${ }^{4}$
}

\section{Analysis of Telephone Consultations at Gifu Pharmaceutical University Pharmacy}

\author{
Nami Kohase ${ }^{1}$, Arihiro Osanai ${ }^{1,2}$, Erika Omata ${ }^{1}$, Akari Shimauchi ${ }^{1}$, Yoko Ino ${ }^{1,2}$, \\ Hirofumi Tamaki, ${ }^{1,2}$, Shuji Yamashita ${ }^{2,3}$, Yoshihiro Noguchi ${ }^{2,4}$, Kazuhiro Iguchi ${ }^{1,2}$ and Hitomi Teramachi ${ }^{* 2,4}$ \\ Laboratory of Community Pharmacy, Gifu Pharmaceutical University ${ }^{1}$, Gifu Pharmaceutical University Pharmacy ${ }^{2}$, \\ Laboratory of Practice and Social Science, Gifu Pharmaceutical University ${ }^{3}$, \\ Laboratory of Clinical Pharmacy, Gifu Pharmaceutical University ${ }^{4}$ \\ [ Received March 9, 2020 ) \\ Accepted July 9, 2020
}

Telephone consultation is an important communication process with patients in community pharmacy. The analysis of the telephone consultation contents provides us with consideration of the problem of medical instruction at community pharmacies. In this study, we investigated the contents of telephone consultations at Gifu Pharmaceutical University Pharmacy and discussed medication instruction at the pharmacy considering the information from telephone consultations. A total of 217 telephone consultations over 4 years were investigated. Patients in a wide range of ages experienced telephone consultations and no gender difference was observed. Although a wide array of drugs was considered in telephone consultations, the consultations about the medicine for cardiovascular diseases were frequently experienced. We also investigated the detailed contents of telephone consultations. In the consultations, 'side effects / drug-drug interactions', 'whether it can be taken or used together' and 'taking or usage method' were major topics. In many cases, patients' lack of understanding led to the consultations, although inefficient explanation by pharmacists also caused the consultations in some cases such as sheet design changes.

Taken together, the investigation of the telephone consultations showed the difficulty of providing precise explanations about the details of drug administration to the patients. This study also showed that the analysis of telephone consultations is useful for finding improvements of medication instruction at a community pharmacy.

Key words — telephone consultation, community pharmacy, medication instruction, side effects

\section{緒言}

日本薬剤師会の処方箋受け取り状況の推計 (https://www.nichiyaku.or.jp/assets/uploads/activities/ bungyo/s/30suikei.pdf, 2019 年 11 月 14 日）によると， 2018 年度には医薬分業率は 74\% となり, 保険薬局 には患者の薬物療法の安全性, 有効性の向上や医 療費の適正に向けて, 地域で暮らす患者本位の医
薬分業の実現に寄与することが求められている.

厚生労働省は, 2015 年 10 月に「患者のための 薬局ビジョン〜「門前」から「かかりつけ」そし て「地域」へ〜」を策定し, かかりつけ薬剤師・ 薬局が持つべき 3 つの機能として, 服薬情報の一 元的・継続的な把握とそれに基づく薬学的管理 · 指導, 24 時間対応 - 在宅対応, かかりつけ医を 始めとした医療機関等との連携強化を挙げてい

\footnotetext{
*テ501-1196 岐阜市大学西1-25-4
} 
る.さらに,「対物業務から対人業務へ」を患者 本位の医薬分業への基本的な考え方としており， 患者に選択してもらえる薬片師・薬局となるため に, 専門性やコミュニケーション能力の向上を通 じ，薬剤の調剤などの対物中心の業務から患者・ 住民とのかかわりの度合いが高い対人業務へと転 換を図ることを示している. ${ }^{1}$

24 時間対応の一環として薬局では, 営業時間外 に薬局を開けて対応するケースや電話による問い 合わせに対しての服薬指導などを行っている. 吉 山らのアンケート調査 ${ }^{2}$ によると, 薬局の原則とし て午前 8 時〜午後 7 時の間に連続して 8 時間以上 の開局時間，休日夜間等緊急時の連絡体制の実現 状況は $80 \%$ と, 多くの薬局において 24 時間対応が 実施され，電話相談も行われていると考えられる. 土井らの報告 ${ }^{3)}$ では, 2010 年〜2011 年に東京都内 にある 23 店舗の薬局において夜間の電話相談数の 合計が月に少なくとも 100 件程度あることが示され ている.ささらに，休日・夜間と通常開局時との間で 薬の相談内容において患者が重要だと思う強さの 違いを評価した小山内らの調査 ${ }^{4}$ では, 夜間・休日 に扔ける重要な相談内容項目は飲み合わせ，緊急 時の対処法, 服薬の可否であることが示され, 通 常開局時に重要だと思う相談内容項目は使用期限, 効能・効果であることが明らかにされた。このこと から患者は薬局に調剂業務だけでなく，飲み合わ せの確認や緊急時の対処法といった薬に関する 様々な相談の対応を求めていることが推測される.

今後, 24 時間対応を始めとした相談業務の必 要性や重要性は高まり, 薬局における電話相談の 件数は今以上に増加していくことが予想される. このことから患者が電話相談によって必要として いる情報を明らかにしておくことは，今後の相談 業務において患者とのコミュニケーションを円滑 に進めるために非常に有用であると考えられる. また，服薬指導時に患者が求めている情報を前 もって伝えることが可能になり, より満足度の高 い服薬指導の実現にも有益である.

当薬局に扔いても 24 時間対応の電話相談を 行っており，相談のあった内容を電話相談内容記 録用紙に記載することとなっている。実際に受け た電話相談のなかには薬剤師の服薬指導等の参考
になると思われる内容が多数見受けられるが, 電 話相談の内容や相談をした患者の特性などを調査 した報告は少ない.

そこで本研究では, 当薬局の電話相談内容を解 析し, 服薬指導の改善点を明らかにすることを目 的として, 実際の相談にどのような傾向がみられ るかを調査した。

\section{方 法}

\section{1. 調査対象}

2015 年 6 月〜 2019 年 4 月の間に電話相談内容 記録用紙に記載のあった 350 件の相談のうち, 電 話相談内容記録用紙に患者氏名の記載があり，か つ薬剂服用歴を参照できる患者からの相談である 217 件を対象とした.

\section{2. 調査項目}

電話相談内容記録用紙からは患者氏名, 相談内 容, 相談のあった薬, 相談のあった時間带を調査 した。また,この情報を基に薬剤服用歴から年齢, 性別を調査した.

\section{3. データの解析}

患者の年齢は年代ごとに分類した．相談のあっ た薬は「国際疾病分類の第 11 回改訂版 (ICD-11)」 を基に分類した，相談内容は記録用紙に記載され た用語を中心に主観的判断で「服用あるいは併用 の可否」,「服用・使用方法」,「効能・効果」,「副 作用・相互作用」, 「薬の過不足」, 「間違った服用・ 使用」, 「調剤の依頼」, 「薬の形状 - 名称」「薬に 関するその他の質問」,「医薬品以外の質問」に力 テゴリー化した，さらに，カテゴリーごとに薬剤 服用歴の記録から相談に至った経緯を調查し, (1) 服薬指導時の説明が十分ではなく電話相談に至っ た例，(2)服薬指導時に説明したが患者の理解が十 分ではなく電話相談に至った例, (3)服薬指導時に 予見できない副作用や併用薬追加などにより電話 相談に至った例に分類した。また，電話相談をし た相談者の年代と当薬局の来局者の年代との関係 性を調べるために 2019 年 4 月における来局者の 年代別割合を用いて相関分析を行った，来局者の 


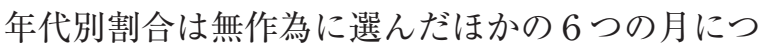
いても同様の傾向を示していたため本解析では 2019 年 4 月のものを用いた.

統計処理には IBM SPSS Statistics 23（日本 IBM (株), 東京）を使用し, 統計的有意水準は, $P<0.05$ とした。

\section{4. 倫理的配慮}

本研究は「人を対象とする医学系研究に関する 倫理指針」を遵守して実施するとともに，岐阜薬 科大学の倫理委員会の承認を得て実施した（承認 番号 : 1-16).

\section{結果}

\section{1. 患者背景}

電話相談を利用した患者の背景は表 1 の通り

表 1 患者背景 $(n=217)$

\begin{tabular}{|c|c|c|c|c|}
\hline & 項目 & $\begin{array}{l}\text { 度数 } \\
\text { (人) }\end{array}$ & $\begin{array}{c}\text { 構成割合 } \\
(\%)\end{array}$ & 家族が電話を \\
\hline 性別 & 男性 & 102 & 47.0 & 割会忠石 \\
\hline 性斻 & 女性 & 115 & 53.0 & \\
\hline & 10 歳未満 & 2 & 0.9 & 100.0 \\
\hline & 10 代 & 3 & 1.4 & 100.0 \\
\hline & 20 代 & 0 & 0.0 & 0.0 \\
\hline & 30 代 & 5 & 2.3 & 20.0 \\
\hline 年龄 & 40 代 & 15 & 6.9 & 13.3 \\
\hline 中相 & 50 代 & 17 & 7.8 & 5.9 \\
\hline & 60 代 & 45 & 20.7 & 4.4 \\
\hline & 70 代 & 88 & 40.6 & 3.4 \\
\hline & 80 代 & 34 & 15.7 & 23.5 \\
\hline & 90 代 & 8 & 3.7 & 62.5 \\
\hline
\end{tabular}

であった．年代別割合については 70 代が多く年 代が若いほど減少していく傾向にあったが, 年代 別相談者数と来局者の年代別割合において相関分 析を行った結果，相談者の年代別割合と来局者の 年代別割合の間には有意に高い正の相関が認めら れた $\left(r_{\mathrm{s}}=0.879, P<0.001\right)$.

また，実際に電話で相談を行ったのが患者本人 または家族であるかを調査した結果，10 歳未満, 10 代の患者はすべて家族が相談を行っているこ とが明らかになった。 また， 80 代と 90 代の患者 では家族が相談を行う割合が高くなることが示さ れた（表 1）。

\section{2. 相談の時間帯}

217 件の相談があった時間帯は業務時間内が $90.3 \%$ ，業務時間外が 9.7\%であった．業務時間外 の相談では「薬の過不足」,「服用あるいは併用の可 否」「服用・使用方法」の相談が多い傾向にあった。

\section{3. 相談のあった薬の分類}

相談のあった薬を「国際疾病分類の第 11 回改訂 版（ICD-11）」に基づいて分類した結果を図 1 に示 す．相談のなかに薬の名前が挙がっている相談を 対象とし， 214 件の相談を分類した，相談のあった 薬の種類に有意差はみられなかったが, 循環器系 の病気に使用される薬の相談が最も多く29件で あった。この相談のなかでは, 高血圧症治療薬で ある $\mathrm{Ca}$ 拮抗薬，アンギオテンシン II 受容体拮抗薬 が多くみられた。呼吸器系の病気に使用される薬

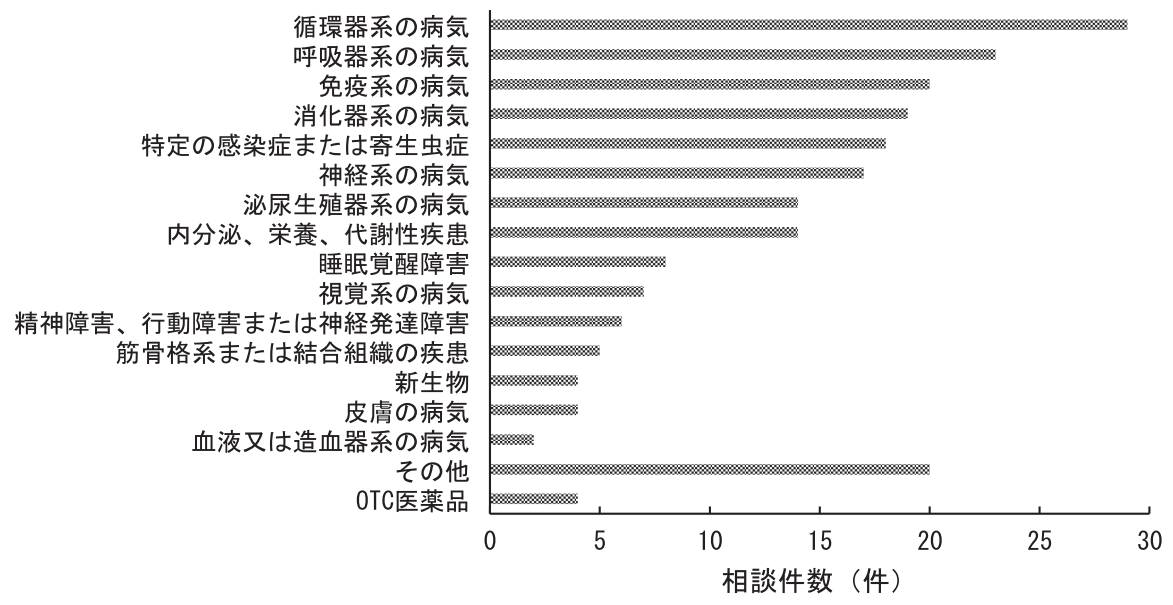

図 1 相談のあった薬の薬効分類 $(n=214)$ 
は鎮咳薬や去痰薬，免疫系の病気に使用される薬 は抗ヒスタミン薬が多くみられ，それぞれ 23 件, 20 件と続いていた．ほかには，特定の感染症また は寄生虫症 (18 件), 神経系の病気 (17 件), 泌尿 生殖器系の病気 (14 件), 内分泌, 栄養, 代謝性 疾患（14 件）などに使用される薬の相談が多いこ とが明らかになった，その他の薬が 20 件あるがこ れらのなかには解熱鎮痛薬（15 件), ビ夕ミン剂（3 件), 漢方薬（2 件）が含まれていた。 また，OTC 医薬品が含まれている相談は 4 件存在した.

\section{4. 相談内容の分類}

相談内容の分類結果について図 2 に示す。1 件 中に複数の相談を受けた場合はそれぞれ別の相談 とみなし，228 件の相談を分類した。全体として は「副作用・相互作用」(39 件)，「服用あるいは 併用の可否」(35 件),「服用・使用方法」(32 件), 「薬の過不足」(30 件)の相談が多い結果となった. 「副作用・相互作用」の相談には薬の飲み合わせ に関する相談，副作用の症状が出た時の対処法の 相談が多く含まれていた。「服用あるいは併用の 可否」では，飲み忘れた薬の服用可否の相談や痛 みなどの症状が治まらないことから追加の服用可 否を相談する患者が多かった。「服用・使用方法」 では薬の用法・用量に関する相談が多くみられ た。また,「効能・効果」,「調剂の依頼」,「薬の 形状・名称」「間違った服用・使用」についての 相談も一定数みられた。「医薬品以外の質問」の 電話相談には患者の体調に関する相談や検査值に ついての相談などがみられた。
カテゴリーごとに電話相談に至った経緯を(1)服 薬指導時の説明が十分ではなく電話相談に至った 例, (2)服薬指導時に説明したが患者の理解が十分 ではなく電話相談に至った例，(3)服薬指導時に予 見できない副作用や併用薬追加などにより電話相 談に至った例に分類した結果, (3)群に該当する相 談がほとんどであったが，(1)群に該当する電話相 談が $7.0 \%$, (2)群に該当する電話相談も $7.0 \%$ 存在 した。カテゴリーごとの(1)群, (2)群, (3)群の割合 を調査した結果, 「副作用・相互作用」,「服用あ るいは併用の可否」,「服用・使用方法」,「薬の過 不足」,「効能・効果」, 「薬の形状 - 名称」で(1)群 と (2)群に該当する相談がみられた（図 3)。(1)群 は「副作用・相互作用」が $2.6 \%$,「服用あるいは 併用の可否」 $8.6 \%$, 「服用・使用方法」 $3.1 \%$, 「薬 の過不足」 $13.3 \%$,「効能・効果」 $16.7 \%$, 「薬の形 状・名称」 $45.5 \%$ であったことから「薬の形状・ 名称」, 「効能・効果」, 「薬の過不足」で服薬指導 時に説明が不足している傾向があった. (2)群は「副 作用・相互作用 $\rfloor 5.1 \%$,「服用あるいは併用の可 否」0.0\%, 「服用・使用方法」 $25.0 \%$, 「薬の過不足」 $6.7 \%$, 「効能・効果」 $8.3 \%$, 「薬の形状・名称」 $27.3 \%$ でった。 また，服薬指導における問題点 を明らかにする目的で(1)群に該当する相談を電話 相談に至った経緯とともにまとめたところ（表 2), 特にシートのデザインや形状変更の説明, 服 用時間や一包化の説明が十分ではないことが明ら かになった。

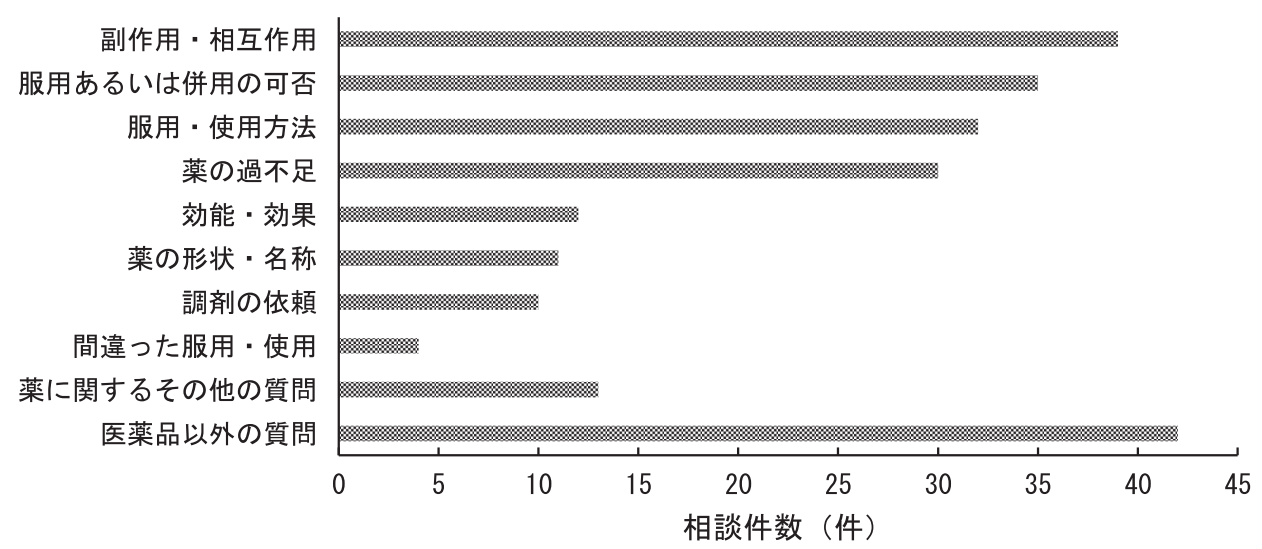

図 2 相談内容の分類 $(n=228)$ 
A

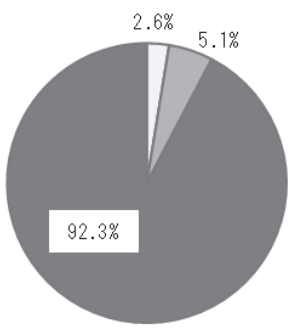

D

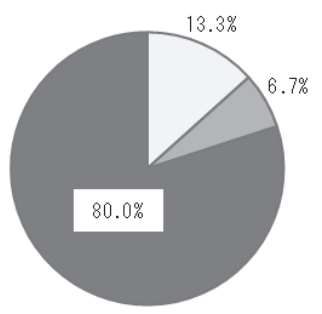

B

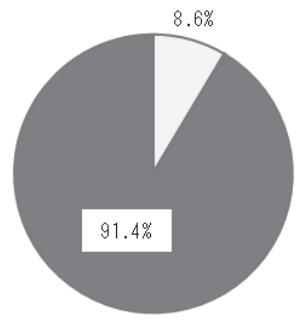

$\mathrm{E}$

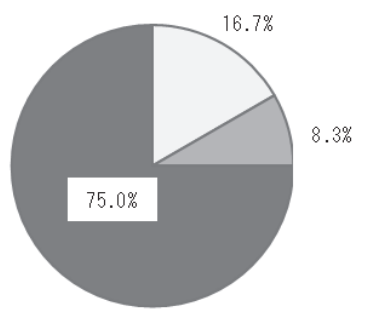

C
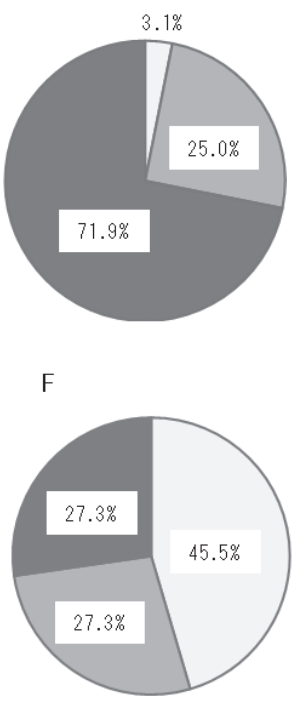

図 3 相談に至った経緯

$A$ ：副作用・相互作用 $(n=39), B$ : 服用あるいは併用の可否 $(n=35), C$ : 服用・使用方法 $(n=32), D$ : 薬の過不足 $(n=30), E$ : 効能 · 効果 $(\mathrm{n}=12), \mathrm{F}$ : 薬の形状・名称 $(\mathrm{n}=11)$. $\square$ (1)服薬指導時の説明が十分ではなく電話相談に至った例, $\square$ (2)服薬指導時に説明した が患者の理解が十分ではなく電話相談に至った例， 口(3)服薬指導時に予見できない副作用や併用薬追加などにより電話相談に至った例.

表 2 服薬指導時の説明が十分ではなく電話相談に至った例

\begin{tabular}{|c|c|c|}
\hline 分類 & 相談内容 & 経緯 \\
\hline $\begin{array}{l}\text { 副作用・ } \\
\text { 相互作用 }\end{array}$ & 、ルナール，アボルブの副作用について知りたい. & $\begin{array}{l}\text { 特にアボルブについての副作用の説明がされていな } \\
\text { かった. }\end{array}$ \\
\hline \multirow{3}{*}{$\begin{array}{l}\text { 服用あるいは } \\
\text { 併用の可否 }\end{array}$} & $\begin{array}{l}\text { 昨日もらったザイザルはリバロと一緒に飲んでもい } \\
\text { いか. }\end{array}$ & 新患であったが併用薬の確認がされていなかった. \\
\hline & $\begin{array}{l}\text { リリカが本日処方されたがロキソニン, カロナール } \\
\text { と併用して大丈夫か. }\end{array}$ & 併用薬の確認がされていなかった. \\
\hline & $\begin{array}{l}\text { エビプロスタットとデスモプレシンの併用は作用が } \\
\text { 真逆な感じがするが大丈夫なのか. }\end{array}$ & $\begin{array}{l}\text { 相談受付時は問題なしと回答したが, その後中止と } \\
\text { なっている. }\end{array}$ \\
\hline $\begin{array}{l}\text { 服用・ } \\
\text { 使用方法 }\end{array}$ & $\begin{array}{l}\text { メネシットいつもは } 1 \text { 回 } 0.5 \text { 錠のところ } 1.5 \text { 錠と記 } \\
\text { 載されているが正しくは何錠ですか. }\end{array}$ & $\begin{array}{l}\text { 薬情への記載ミスだが, 投薬時に説明を䍐ったため } \\
\text { 発見できなかった. }\end{array}$ \\
\hline \multirow{4}{*}{ 薬の過不足 } & プレドニンが足りないです. & $\begin{array}{l}\text { プレドニンは隔日投与だったが説明が不足していた } \\
\text { ため毎日服用してしまっていた. }\end{array}$ \\
\hline & 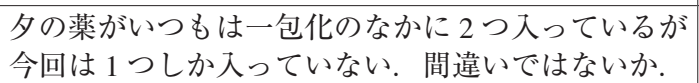 & $\begin{array}{l}\text { 夕食後服用であったクレストールが朝食後に変更に } \\
\text { なっていたが，説明がされていなかった. }\end{array}$ \\
\hline & $\begin{array}{l}\text { 今日からエクメット LD に変わったけど半分しか } \\
\text { 入っていないと思う. }\end{array}$ & $\begin{array}{l}\text { 朝の薬のみ一包化している患者で, PTP で調剤した } \\
\text { 夕方分は説明したが朝も一包化に追加されているこ } \\
\text { との説明をしなかった. }\end{array}$ \\
\hline & $\begin{array}{l}\text { ワーファリンの量がこれではおかしいと思うので確 } \\
\text { 認してほしい. }\end{array}$ & $\begin{array}{l}\text { 医師の処方ミスで } 1.25 \mathrm{mg} \text { のところを } 2 \mathrm{mg} \text { で処方. } \\
\text { 確認不足により } 2 \mathrm{mg} \text { のまま投薬してしまった. }\end{array}$ \\
\hline \multirow{2}{*}{ 効能・効果 } & $\begin{array}{l}\text { ルリッドを飲んでいるがこれは風邪を治すために飲 } \\
\text { んでいるのですか. }\end{array}$ & ルリッドの薬効について説明がされていなかった. \\
\hline & $\begin{array}{l}\text { 今日追加になっているパンテチン, 酸化 } \mathrm{Mg}, \quad \text { フル } \\
\text { ニトラゼパムが何の薬か知りたい. }\end{array}$ & $\begin{array}{l}\text { 患者が急いでいたため新規処方薬について説明がさ } \\
\text { れていなかった. }\end{array}$ \\
\hline \multirow{5}{*}{ 形状·名称 } & $\begin{array}{l}\text { オノンのシートが前の残りと違っているが薬が変 } \\
\text { わったのか. }\end{array}$ & $\begin{array}{l}\text { シートのデザイン変更について説明がされていな } \\
\text { かった. }\end{array}$ \\
\hline & $\begin{array}{l}\text { この前もらった薬の形が前と違うが薬が変更になっ } \\
\text { たのか. }\end{array}$ & $\begin{array}{l}\text { グラクティブの形状変更について説明がされていな } \\
\text { かった. }\end{array}$ \\
\hline & $\begin{array}{l}\text { サイレースじゃない薬が入っている気がする.この薬 } \\
\text { を飲むと食欲が異常に増進するが別の薬ではないか. }\end{array}$ & $\begin{array}{l}\text { サイレースの色の変更について説明がされていな } \\
\text { かった. }\end{array}$ \\
\hline & $\begin{array}{l}\text { ジェネリックで薬がでているからノルバスクに代え } \\
\text { て欲しい. }\end{array}$ & $\begin{array}{l}\text { 先発品希望の方だったが, 一般名処方であったため } \\
\text { ジェネリックで調剤し，患者への説明を意ってし } \\
\text { まった. }\end{array}$ \\
\hline & $\begin{array}{l}\text { ユリーフ普通錠から OD 錠への切り替えの説明がな } \\
\text { かった. }\end{array}$ & $\begin{array}{l}\text { 普通錠から OD 錠への変更の説明がされていなかっ } \\
\text { た. }\end{array}$ \\
\hline
\end{tabular}




\section{考察}

本研究では，実際にあった電話相談の記録から その内容を調査し, 服薬指導の改善点を明らかに することを試みた。

当薬局に来局する患者は表 1 より 60 代から 80 代の患者が多いが，年代別相談者数と来局者の年 代別割合に有意に正の相関がみられたことから， 電話相談はどの年代においても同程度の割合で行 われていることが明らかになった．どの年代の患 者においても薬や治療に関する質問や不安を持っ ていると考えられる。

家族が電話相談をした割合が 80 代から 90 代で ほかの年代と比較して高くなっていることが明ら かになった，高齢になるにつれて患者本人が薬を 管理することが難しくなり，家族が管理をしてい ることが理由であると考えられる。また，薬の管 理だけでなく受け取りも家族が行っている高齢患 者も存在しているため, 薬の管理者を服薬指導時 に把握しておくことが重要であると推察される. 実際の相談のなかには，家族が薬の受け取りをし ている患者に拈いて，患者の電話相談から間違っ た服用をしていることが明らかになった例があ る.この例では薬剤師から患者家族と患者家族か ら患者本人の間で正しく情報が伝わらなかった可 能性があり，薬剤情報提供書やお薬手帳を用いて 家に帰った後に再度確認するように促すことが重 要であると考えられる.

また，電話相談を受けた時間帯については，業 務時間内が $90 \%$ 以上を占めたが，業務時間外や 休日の相談には，服用すべき薬がない，薬の服用 方法がわからないなど緊急を要するものも多い. 今後は，業務時間外や休日でも，電話相談を応需 することを周知し，問題を解決して患者の適切な 服薬を進めるべきであると考えられる。

相談のあった薬は循環器系の病気に使用される 薬，呼吸器系の病気に使用される薬，免疫系の病 気に使用される薬の相談件数が多かった. しかし, それ以外の薬についても一定数相談があり, 偏り はみられなかったことから，電話相談において薬 の種類よりも相談内容のほうが重要であると考え られる。
当薬局における相談内容では，「副作用・相互 作用」,「服用あるいは併用の可否」,「服用・使用 方法」,「薬の過不足」の 4 項目が多いことが明ら かになった。これらの相談は特に患者が疑問や不 安を感じ，相談をする確率が高い内容であること が考えられる。また，電話相談に至った経緯を調 査した結果，服薬指導時の説明が十分ではなく電 話相談に至った例は全体の $7.0 \%$ あり，「薬の形 状・名称」,「効能・効果」,「薬の過不足」で説明 が十分ではないことが明らかになった．特に「薬 の形状・名称」は約半数が説明不足であり, 表 2 から患者は薬の些細な変化によって不安を感じ電 話相談に至ったと推察されるが，薬剤師において はシートのデザイン変更や形状, 色調の変更は重 要性が低く, 服薬指導時の説明が十分に行われて いないと考えられる。薬剤師はこのような患者と の認識の差を理解したうえでデザイン変更等の説 明も行うべきであることが示唆された。服薬指導 時に説明したが患者の理解が十分ではなく電話相 談に至った例は「服用・使用方法」「効能・効果」, 「薬の形状・名称」で多いことが明らかになった。 今西らの患者と薬局薬剤師間における服薬指導内 容項目の重要度および実施率(患者では被実施率) を比較した研究 ${ }^{5)}$ では, 服薬指導項目 21 項目の うち 19 項目において薬局薬剤師の実施率が患者 の被実施率より高いという結果が報告されてお り, 薬剤師は服薬指導時に説明をしていると自己 認識しているが，患者側にうまく伝わっていない 可能性が高いことが報告されている。 また，これ までに患者の内服薬の理解度や吸入方法の理解度 を調査した結果, ${ }^{6}$.7) いずれにおいても 60 代から 年齢が増すにつれて理解度が低下する傾向がある ことが示されている。薬剤師はこのような背景を 知ったうえで，「服用・使用方法」，「効能・効果」 ではわかりやすい説明を行い，理解できなかった ことがないか確認すること,「薬の形状・名称」 では先発品と後発品の名称の違いについて十分説 明する必要があることが示唆された.

本研究により，患者の年代や服用薬の種類に差 はみられなかったが，相談内容は「副作用・相互 作用」，「服用あるいは併用の可否」に関する相談 が多く, 薬の形状やデザイン変更などは説明が十 
分されていないことも明らかになったままた,「服 用・使用方法」は服薬指導時に薬剂師が説明を 行っていても患者の理解が十分ではなく相談に繋 がる可能性が高いことが明らかになった，今後薬 凨師は，簡単でわかりやすい説明や患者の理解度 を確認するよう努め, 薬のデザイン変更等の説明 を十分に行うことでよりよい服薬指導になると考 える。

なお，本研究は当薬局における電話相談内容の 解析という限定的なものである。 また，薬局の立 地によっても相談内容は変化することが考えられ る. しかし, 本研究は電話相談内容を解析するこ とによって服薬指導の改善点を見つけることが可 能であることを明らかにした数少ない研究であ り, 今後の薬局における相談業務や服薬指導の充 実を図る際の一助になったといえる.

\section{利益相反}

開示すべき利益相反はない.

\section{引用文献}

1）厚生労働省, 患者のための薬局ビジョン〜「門 前」から「かかりつけ」, そして「地域」へ〜，
2015年10月23日．

2）吉山友二, 川上美好, 成川 衛, 安部好弘, 森 昌平, 山本信夫, 佐々木均, 安原眞人, 「薬局の求 められる機能とあるべき姿」に関する薬局開設 者・管理者へのアンケート調査, 医療薬学, 2015, 41, 424-434.

3）土井信幸, 坪井 賢, 中澤 巧, 中野宣範, 保険薬 局における夜間24時間対応の問い合わせ内容の 推移から評価したお薬手帳の適正使用による有 効性, 医療薬学, 2012, 38, 204-209.

4）小山内康徳, 木村礼志, 高杉公彦, 櫻井秀彦, 休 日・夜間と通常時に扔ける薬の相談内容に関す る重要度の相違とその評価, 医療薬学, 2018, 44, 288-298.

5） 今西孝至, 大川裕加里, 高山 明, 保険薬局にお ける服薬指導に関する患者・薬剤師間の双方向 性調査, 医療薬学, 2014, 40, 660-664.

6）市東友和, 高橋京子, 山浦真弓, 矢島愛治, 大城 㻟磨, 萩原みさを, 外来透析患者に打ける内服 薬の理解度に関する統計学的解析, 医療薬学, 2003, 29, 532-538.

7）野見山順子, 彦田絵美, 山崎智司, 小野寺美琴, 諸星総一, 小坂好男, 秋吉恵蔵, 小杉依子, 浅野明 日香, 桂 秀樹, 地域調剤薬局における吸入指 導の実態調查, 日本呼吸ケア・リハビリテー ション学会誌, 2010, 20, 42-48. 